\title{
TRANSLATION ANALYSIS IN SENTENCE PATTERNS FOUND IN THE NOVEL "BUDDHA"
}

\author{
I Made Juliarta \\ English Department, Bali Dwipa University, Denpasar Bali \\ Madejuliarta@balidwipa.ac.id
}

\begin{abstract}
This study aims to: (i) analyze the tree diagram structure of sentence patterns found in the data source, (ii) analyze the types of translation shifts of sentence patterns in the translation process from source language into target language. The novel entitled "Buddha" is a non-fiction book by Karen Armstrong. It tells about an examination of the life, times, and lasting influence of Siddharta Gautama with core tenets of Buddhism introduced throughout history. This research focuses on The Syntax Analysis and Its Translation Found on Sentence Patterns in the Novel entitled "Buddha". This study aims at analyzing the tree diagram structure and the types of translation shifts found in the novel entitled "Buddha". The analysis uses the theory of sentence patterns from Quirk and Greenbaum and the theory of translations shift proposed by Catford. The process of collecting data was started by reading the entire data source to understand the story in the novel entitled "Buddha" and observe the data of sentence patterns that can be taken from the story entitled "Buddha". In the method of collecting data, the data source was read to find out complex sentences and simple sentence found in the story. The finding of the research is that there are seven sentence patterns that are translated by applying unit shift. The researcher uses the theories to support this research. Those are syntax, types of sentences, sentence pattern, tree diagram, and relevant previous studies. Syntax is stated as one of the branches that focus on the sentence structure. This research study uses theory of translation shift proposed by Catford.
\end{abstract}

Keywords: Simple sentence, Complex sentence, Syntax

\section{Introduction}

We can do communication with each other when we have at least one language. Human can show feelings and emotions by using languages. A sentence is a grammatical unit in which there are one or more words. An idea, a question, subject and statements are expressed by words and as we know that a sentence usually contains a subject and a verb. Phrases and sentences can be built up of constituent series (syntactic units). It is seen that the arrangement and the form of word are related in a sentence. A sentence consists of subject, verb, complement, object and 


\section{International Journal of Linguistics and Discourse Analytics}

Vol.2, No.2, March 2021

P-ISSN 2721-8899 E-ISSN 2721-8880

adverbial (SVCOA). Language can be used to express their feeling, ideas, knowledge and thought. Sapir (1921) stated that the language as "a purely human and non-instinctive method of communicating ideas, emotions and desires by means of a system. O'Grady (2005) asserts that 'if a language is spoken, it must have a phonetic and phonological system; since it has words and sentences, it must also have a morphology and syntax system". Sentence is considered as one of the most complex parts in language. Hornby (2015) stated that sentence is defined as a set of words expressing a statement, a question or an order, usually containing a subject and verb. People should produce sentences in order to use language. Sentence is considered as one of the most complex parts in language. Horny (2015) stated that sentence is defined as a set of words expressing statement, a question, or an order. It usually contains a subject and a verb. At least in a sentence, it consists of a subject and a verb. A sentence consisting of a subject and a verb is stated as a simple sentence. The linguistic branch that studies about how sentences are formed are stated as syntax. Syntax is stated as the system of rules and categories underlying sentence formation in human language. Radford (1997) stated that syntax focuses on how words are put together in order to form phrases and sentences. Syntactic patterns, syntactic construction, and system of rules can be discussed in the syntax. One of the linguistics branches that study about the grammatical concepts and patterns of sentence is called syntax. People can develop their knowledge and know something by using language. The researcher chooses the novel entitled "Budha" as the data source because it contains few patterns that can be analyzed syntactically. By doing this research, the researcher hopes that the reader gets the point and gets deeper information about syntactic analysis on sentence patterns found in the novel entitled "Budha". The researcher focuses on the analysis of syntax on simple sentence and their translations found in the novel entitled "Budha". In the translation analysis, the researcher uses the theory proposed by Catford (1965), in analyzing about the shift in translation. The researcher chooses this theory as it gives more deeper information related to the translation analysis discussed in this research. English learners usually do not get familiar enough to English sentence patterns. English learners usually know about the English words class such as nouns, pronouns, verbs, adjective, adverbs, prepositions, and articles or determiners. The words can be put together in the correct order. Language has the role to do communication and interactions. Chaer and Agustina (2010:1) stated that there are two kinds in factor of language, those are external and internal factors. It is stated that in external factors, language can be related to other contexts, such as the various functions of language and the social situation. The study of language uses linguistic science and other sciences (Psychology and sociology). It is stated in internal factors that language is an analysis in term of language structure. For example, it can be seen in syntax, vocabulary, phonology, and morphology.

According to Chaer (2007:15), internal language structure is stated as object of micro linguistics involving system of sound, word information, and sentence structure. Syntax is the 


\section{International Journal of Linguistics and Discourse Analytics}

Vol.2, No.2, March 2021

P-ISSN 2721-8899 E-ISSN 2721-8880

study of the rules governing the way words that is combined to form sentences in a language. A literary work can be used by the people in order to express an imagination. Prose, poetry and drama can be called as the genres of literary work. Prose in novel is dominant in social element. Novel tells about complex story. Language can be used as a tool to communicate. The differences in language are in style, vocabulary, grammar and syntax. Short words can be used by the children to communicate with people. Long words are used by adults consisting of main clause and subordinate clause (compound sentence or complex sentence). Short story or novel is used to introduce literary works. The researcher is interested in analyzing novel entitled "Buddha" as one of the literary works that is intended to be read by adults. The researcher discusses the translation analysis found on sentence patterns in the novel entitled "Buddha".

Reviews of related literature were explained in this study. First is the research from Prawita (2014) in her thesis describes about the types of shift of complex noun phrase occur in the translation of Oprah from English into Indonesian. She discussed about shift in translation of complex noun phrase. She applied the theory that was proposed by Catford (1965) in A Linguistic Theory of Translation and Nida (1975) in Language Structure and Translation. The weakness of this thesis found that there was no relation between the main and supporting theory. The writer chose this thesis as one of the reviews as this thesis gives clear explanation about the types of shift which occurred in complex noun phrase. This thesis gives a contribution in analyzing data using the theory of translation shift in this research study.

The second related literature is Agustini (2005) in her thesis describes the type and function of nominal clause in the novel the Official deat by Prescott which was published in 2003. All major of the relative clauses were found in the data. This analyses also showed about the function of the nominal clause depending on their types. The strength of this thesis is on the relevance between nominal clause and relative clause analysis. The writer chose this thesis as one of the reviews because it relates to the topic that was discussed by the writer. This writing used the theory of translation equivalence and Quirk et all. The third related literature was written by Astuti (2005). The writer analyzed on the structure of English Noun Phrase (ENP) as the Source Language (SL) translated into Indonesian Noun Phrase (INP) as the Target Language (TL). The equivalence translation of English Noun Phrase into Indonesian was analyzed in this research study. The writer chose this graduate thesis as one of the reviews because it related to the topic discussed by the writer. The writer chose this thesis as one of the reviews because this undergraduate thesis gave clear explanation about the definition of translation equivalence. The difference between Astuti's undergraduate thesis and this research study are about the theory which was used to solve the problem. The fourth related literature was written by Kamil (2014) entitled An Analysis of English-Indonesian Translation Quality on Twitter Web Pages. This study was chosen as one of related literature as this study discussed about characteristics of good translations to achieve the goals to attain the real message of the text. The fifth related literature 
International Journal of Linguistics and Discourse Analytics

Vol.2, No.2, March 2021

P-ISSN 2721-8899 E-ISSN 2721-8880

entitled "Comparison of Human Translation with Google Translation of Imperative Sentences in Procedures Text". This study was chosen as one of the related literatures as this study discussed about human translation and machine translation in translating procedural texts.

\section{Methods}

The method of collecting data in this study was done by observation and documentary analysis. The observation method was used to observe the entire data that contained declarative sentences in the source language and their translations in the target language. The techniques of collecting data in the source language were done by note taking, reading and doing observation. In the process of collecting the data, the data were read to know the story that was found in the novel "Buddha" and continued to observe the possibility of the data that were taken from the novel. Firstly, the entire novels were read in order to get the data of declarative sentence and analyzed the syntactic structure. After that, it was continued to select the data based on the problems that were discussed in this research study. The declarative sentence and its syntactic structure were then analyzed. Finally, it was continued to analyze the types of translation shifts of relative clauses occurred in the translation of the novel entitled "Buddha".

\section{Findings and Discussion}

This section concerned with the tree diagram analysis and translation analysis from English into Indonesian. Translation shift in sentence patterns were analyzed by using the theory that was proposed by Catford. The tree diagram and the translation shift analysis were presented descriptively as follows.

Datum 1

I will kill him personally!

Akan kubunuh dengan tanganku sendiri. (13)

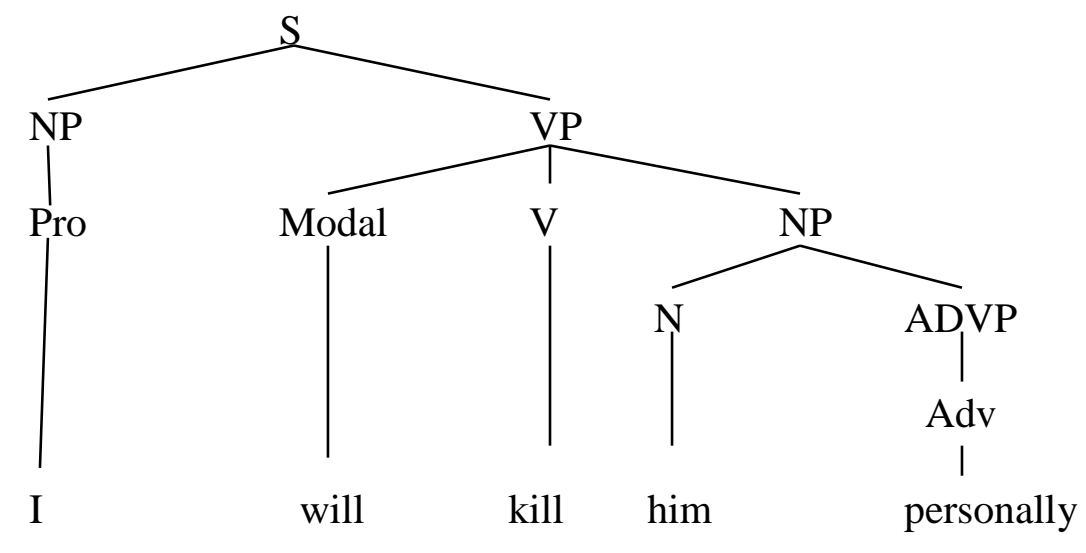


International Journal of Linguistics and Discourse Analytics

Vol.2, No.2, March 2021

P-ISSN 2721-8899 E-ISSN 2721-8880

It can be seen from the structure in the sentence I will kill him personally that the simple sentence has the constituent structure of NP and VP. The VP consists of modal, verb, and noun phrase. We can see from the strucure as follows:

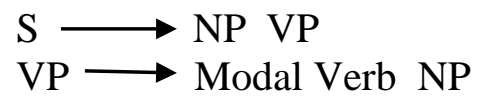

By looking at the tree diagram in text I in the sentence I will kill him personally, it can be seen from the text that unit shift occured in the proccess of translation. A shift of an adverb into a phrase occured in the translation process above. As a part of simple sentence, an adverb personally was translated into a phrase dengan tanganku sendiri. The translation equivalent in the target language occurs at a different rank into a phrase dengan tanganku sendiri. Unit shift is a stretch of language activity that is the carrier of a pattern of a particular kind. This type of shift is called as unit shift that is a change in higher rank translated from an adverb personally into a phrase dengan tanganku sendiri.

Datum 2

I want more soldiers now

Aku ingin lebih banyak serdadu.

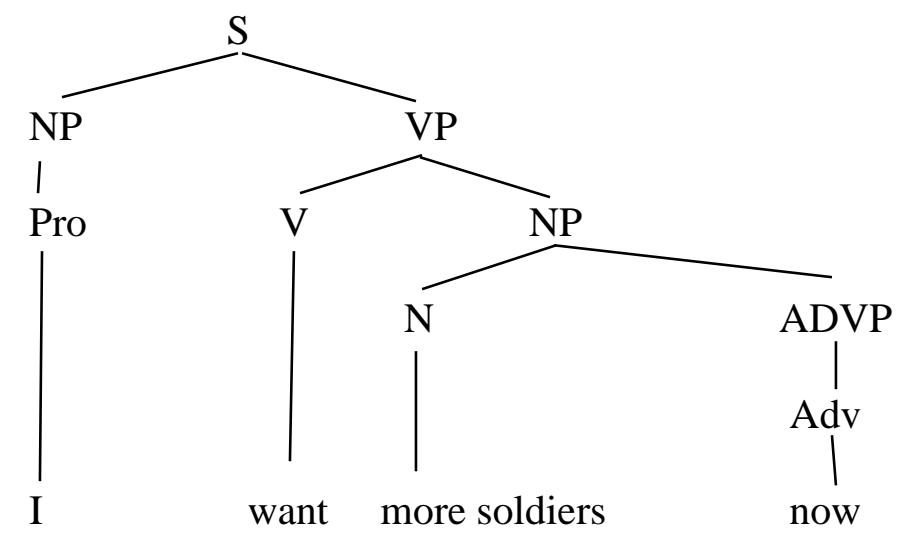

It can be seen from the structure in the sentence I want more soldiers now that the simple sentence has the constituent structure of NP and VP. The VP consists of verb and noun phrase. We can see from the strucure as follows:

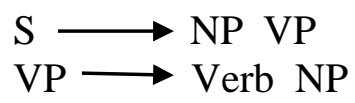

By looking the tree diagram in text II in the sentence I want more soldiers now, it can be seen from the text that unit shift occured in the proccess of translation. A shift of a word more is translated into a phrase lebih banyak in the translation process above. As a part of simple 
sentence, a word more was translated into a phrase lebih banyak. The translation equivalent in the target language occurs at a different rank into a phrase lebih banyak. This type of shift is called as unit shift that is a change in higher rank translated from a word more into a phrase lebih banyak.

\section{Datum III}

He spoke quietly (13)

Ia berkata lirih (11)

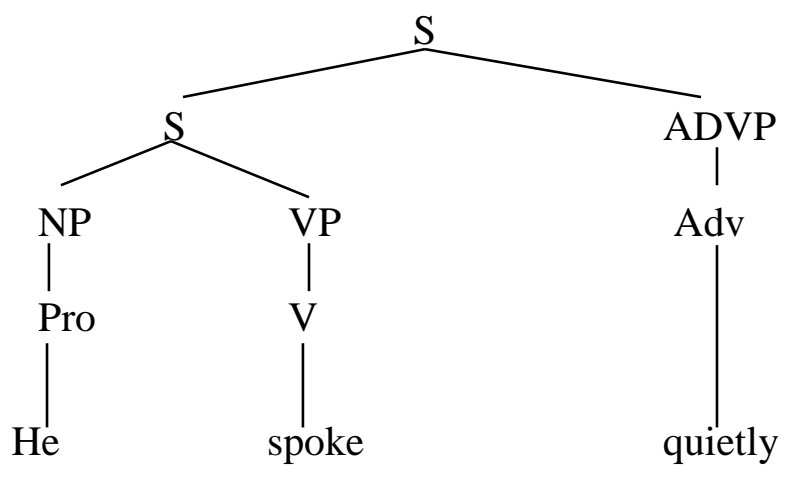

It can be seen from the structure in the sentence He spoke quietly that the simple sentence has the constituent structure of NP and VP. The VP consists of verb and noun phrase. We can see from the strucure as follows:

$$
\begin{aligned}
& \mathrm{S} \longrightarrow \mathrm{NP} \text { VP } \\
& \mathrm{VP} \longrightarrow \text { Verb ADVP }
\end{aligned}
$$

\section{Datum IV}

I want to crush their line.

Aku ingin menghancurkan barisan mereka.

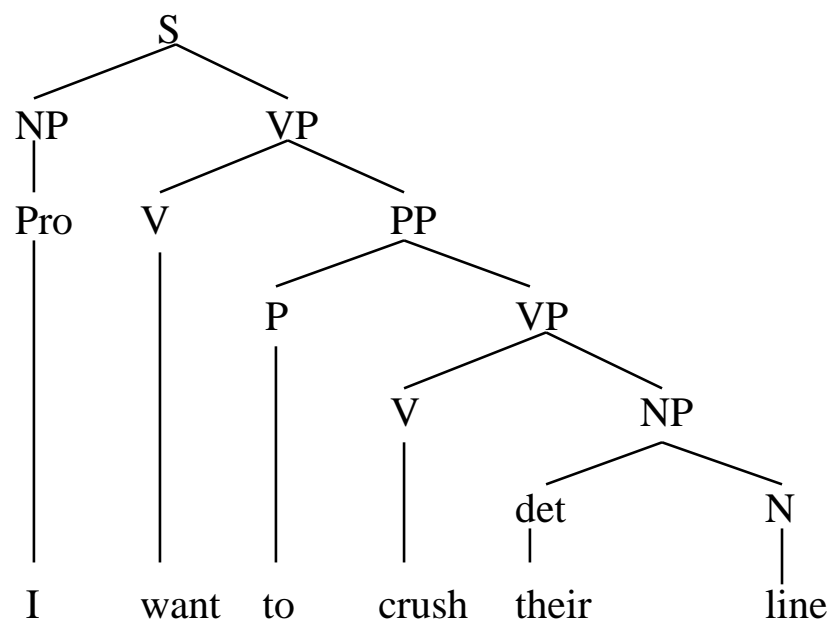


It can be seen from the structure in the sentence I want to crush their line that the simple sentence has the constituent structure of NP and VP. The VP consists of verb and prepositional phrase. We can see from the strucure as follows:

$\mathrm{S} \longrightarrow \mathrm{NP} \mathrm{VP}$

$\mathrm{VP} \longrightarrow$ Verb PP

$\mathrm{PP} \rightarrow \mathrm{P}$ VP

$\mathrm{VP} \longrightarrow \mathrm{V}$ NP

Datum V

Destiny guided her there.

Tangan nasib menuntunnya ke tempat itu. (15)

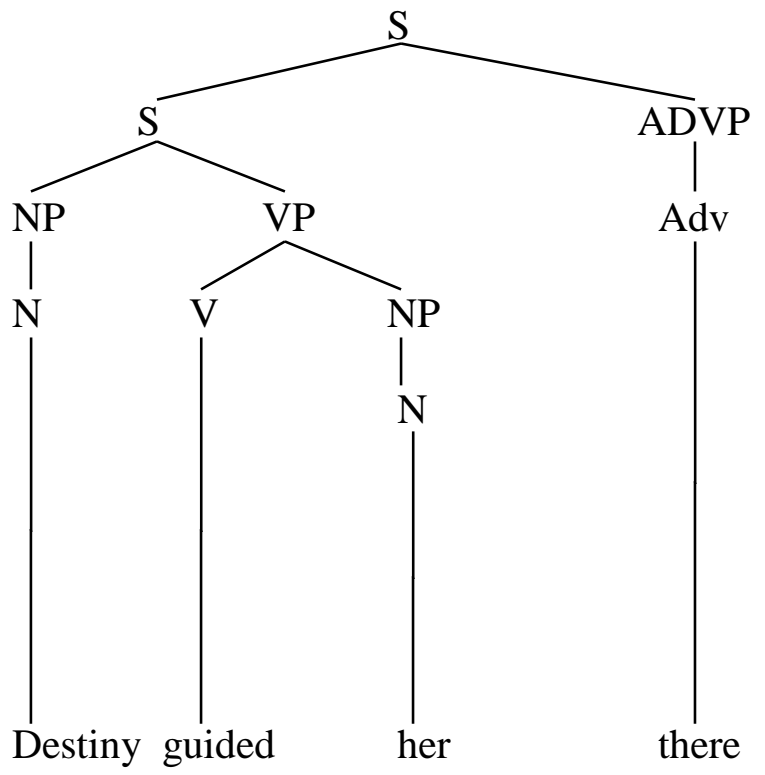

It can be seen from the structure in the sentence destiny guided her there that the simple sentence has the constituent structure of NP and VP. The VP consists of verb and noun phrase. We can see from the strucure of the simple sentence as follows:

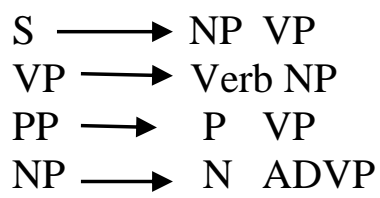

By looking at the tree diagram in the sentence destiny guided her there, it can be seen from the text that unit shift occured in the proccess of translation. A word destiny is translated into a phrase tangan nasib in the translation process above. As a part of simple sentence, a word destiny was translated into a phrase tangan nasib. The translation equivalent in the target 
International Journal of Linguistics and Discourse Analytics

Vol.2, No.2, March 2021

P-ISSN 2721-8899 E-ISSN 2721-8880

language occurs at a different rank into a phrase tangan nasib. This type of shift is called as unit shift that is a change in higher rank translated from a word destiny into a phrase tangan nasib.

Datum VI

Her breath caught in her throat.

Napasnya tercengat di kerongkongan.

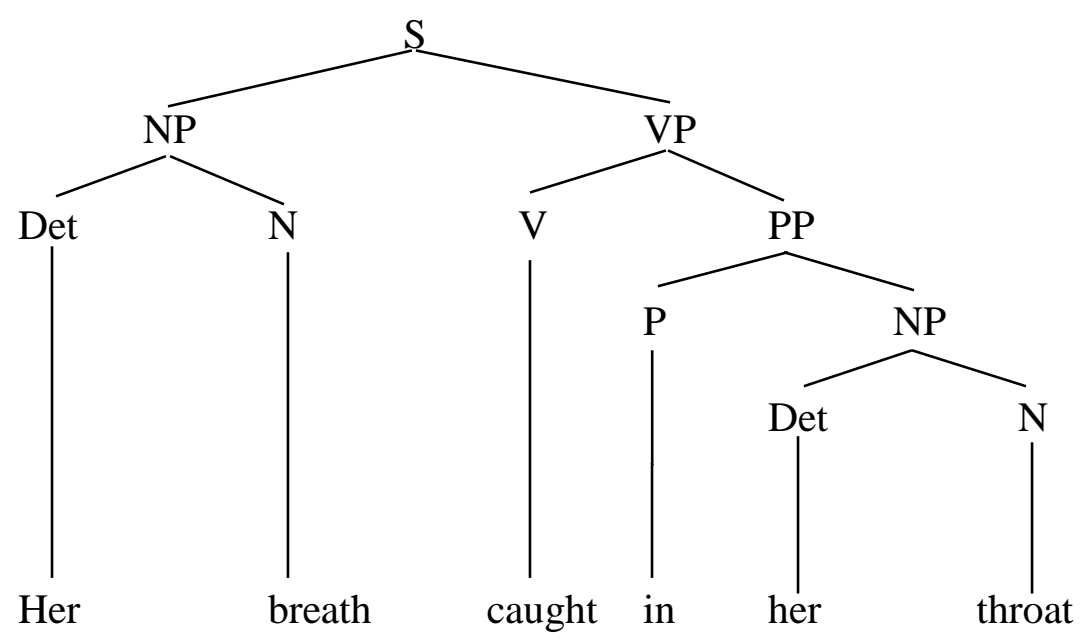

It can be seen from the structure in the sentence her breath caught in her throat that the simple sentence has the constituent structure of NP and VP. The VP consists of verb and prepositional phrase. We can see from the strucure of the simple sentence as follows:

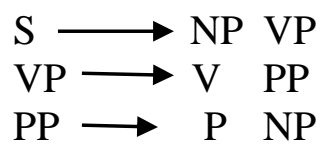

By looking at the tree diagram in the sentence her breath caught in her throat, it can be seen from the text that unit shift occured in the proccess of translation. A phrase her breath is translated into a word napasnya in the translation process above. As a part of simple sentence, a phrase her breath was translated into a word napasnya. The translation equivalent in the target language occurs at a different rank into a word napasnya. This type of shift is called as unit shift that is a change in lower rank translated from a phrase her breath into a word napasnya.

Datum VII

Her head sank into the pillow. (20)

Kepalanya melesak ke bantal. (22) 
Vol.2, No.2, March 2021

P-ISSN 2721-8899 E-ISSN 2721-8880

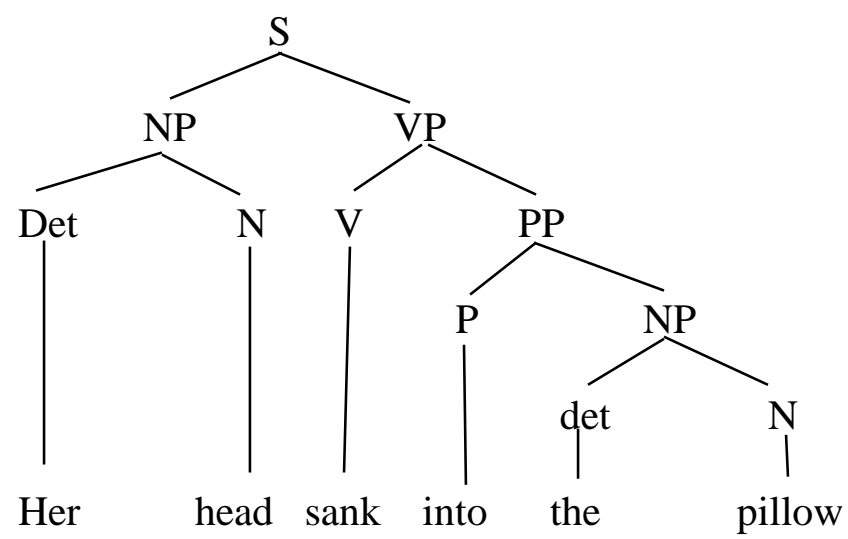

It can be seen from the structure in the sentence her head sank into the pillow that the simple sentence has the constituent structure of NP and VP. The VP consists of verb and noun phrase. We can see from the strucure of the simple sentence as follows:

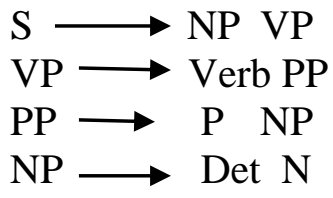

By looking at the tree diagram in the sentence her head sank into the pillow, it can be seen from the text that unit shift occured in the proccess of translation. A phrase her head is translated into a word kepalanya in the translation process above. As a part of simple sentence, a phrase her head was translated into a word kepalanya. The translation equivalent in the target language occurs at a different rank into Indonesian word kepalanya. This type of shift is called as unit shift that is a change in lower rank translated from a phrase her head into a word kepalanya.

\section{Datum VIII}

I have been blessed. (20)

Aku telah diberkati. (21)

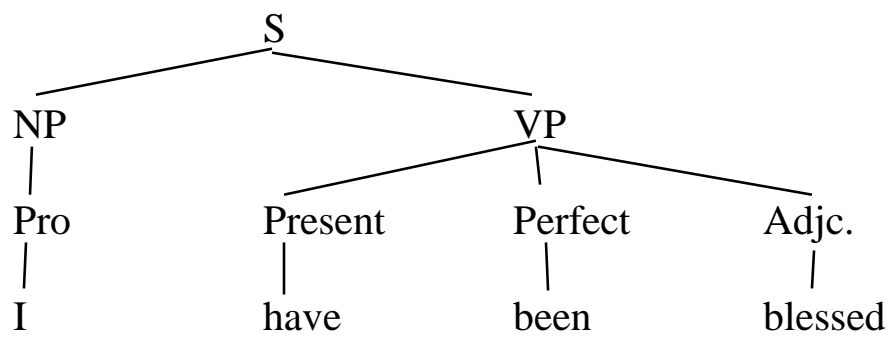


International Journal of Linguistics and Discourse Analytics

Vol.2, No.2, March 2021

P-ISSN 2721-8899 E-ISSN 2721-8880

It can be seen from the structure in the sentence I Have been blessed that the simple sentence has the constituent structure of NP and VP. The VP consists of present, perfect and adjective. We can see from the strucure of the simple sentence as follows:

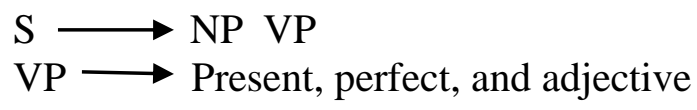

By looking at the tree diagram in the sentence I have been blessed, it can be seen from the text that unit shift occured in the proccess of translation. A phrase have been is translated into a word telah in the translation process above. As a part of simple sentence, a phrase have been was translated into a word telah. The translation equivalent in the target language occurs at a different rank into Indonesian word telah. This type of shift is called as unit shift that is a change in lower rank translated from a phrase have been into a word telah.

Datum IX

He who has attained all desires.

Dia yang tercapai segala cita-citanya. (17)

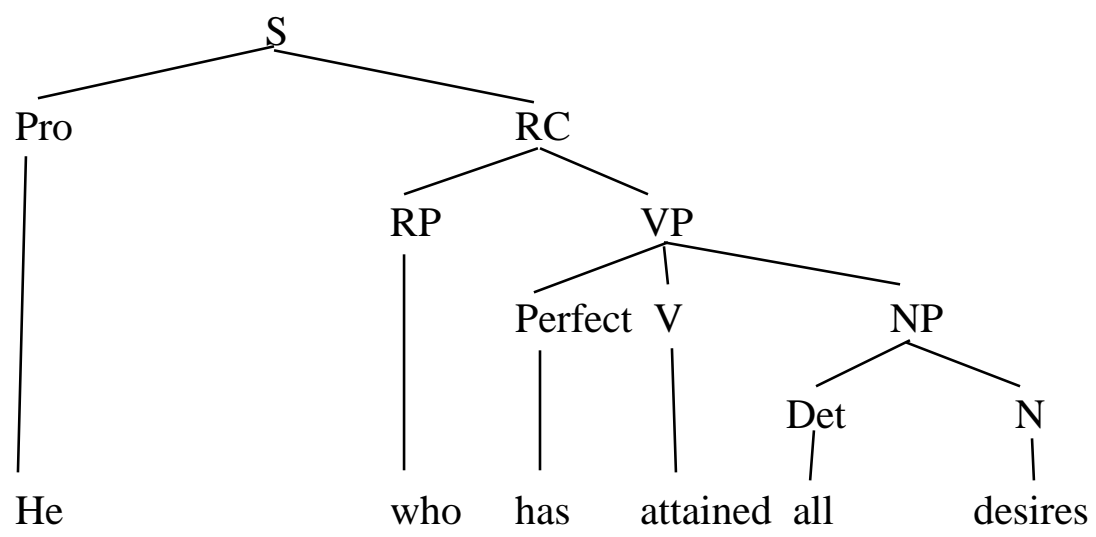

It can be seen from the structure in the sentence He who has attained all desires that the sentence has the constituent structure of pronomina and relative clause. The relative clause consists of relative pronoun and verb phrase. We can see from the strucure of the relative clause as follows:

$\mathrm{S} \longrightarrow$ Pronomina Verb phrase

$\mathrm{VP} \longrightarrow$ Perfect, verb and noun phrase

By looking at the tree diagram in the sentence he who has attained all desires, it can be seen from the text that unit shift occured in the proccess of translation. A word desires is translated into a phrase cita-citanya in the translation process above. As a part of simple sentence, a word desires was translated into a phrase cita-citanya. The translation equivalent in 


\section{International Journal of Linguistics and Discourse Analytics}

Vol.2, No.2, March 2021

P-ISSN 2721-8899 E-ISSN 2721-8880

the target language occurs at a different rank into Indonesian phrase cita-citanya. This type of shift is called as unit shift that is a change in higher rank translated from a word desires into a phrase cita-citanya.

\section{Conclusion}

Syntactically, the structure categories of each lexical item are represented by sentence pattern. This research uses the theory of sample patterns that is proposed by O'Grady, Dobrovolsky, and Katamba (1996) to analyze the sentence patterns. Lexical can be in Noun (N), Verb (V), Adjective, Preposition, and Adverb. In noun phrase, it is modified by determiners and adjective. In verb phrase, it consists of a single verb by a noun phrase, adverb phrase, and prepositional phrase. Adverb phrase is a head that is followed by modifying elements. Adjective phrase consists of an adjective as a head followed by modifying elements. Possesive phrase is constructive by an apostrophe before noun phrase.

This research study uses theory of translation shift that is proposed by Catford (1965) stating that shift is the departure from formal correspondence in the process from the source language into target language. Catford (1965) divides the shift in translation into two major types. Those are level/rank shift and category shift. Shifts are categorized into (1) Shift of level and (2) shift of category. According to Catford (1965) cases of shifts from grammar to lexis are quite frequent in translation between languages. Level/rank shift refers a source language item at one linguistic level that has a target language translation equivalent at a different level. In the category shift, it is divided again into structure shifts, class shifts, unit shift, and intra-system shifts. Structure shift is the process of changing of words sequence in a sentence.

\section{Acknowledgement}

In this great opportunity, the researcher would like to express deep greatest thanks to the Head of English Department, Bali Dwipa University in giving suggestions, direction, and support to complete the article. Therefore, the researchers have the knowledge in doing the research related to the syntax field.

\section{References}

1] Alwi, Hasan, et al. 2003. Tata Bahasa Baku Bahasa Indonesia. Jakarta: Balai Pustaka

2] Bell, R. T. 1991. Translation and Translating. Theory and Practice. London and New York: Longman.

3] Catford, J.C. 1965. A Linguistic Theory of Translation. London: Oxford University Press.

4] Chomsky, Noam. 2002. Syntactic Structures (2nd ed.). Berlin: Mouton de Gruyter

5] Hudson, R.A. 1998. Sociolinguistics. Cambridge: Cambridge University Press. 
International Journal of Linguistics and Discourse Analytics

Vol.2, No.2, March 2021

P-ISSN 2721-8899 E-ISSN 2721-8880

6] Halliday, M.A.K. (1994). An Introduction to Functional Grammar. London.: Edward Arnold

7] Hatim, B and Munday,J. 2004. Translation: An Advance Resource Book. London and New York: Routledge 